\title{
The Shadow Database: Activism, Art, and Aspiration within Urban Regeneration
}

\section{TOM KEENE}

Ph.D. Researcher, Department of Design, Goldsmiths, University of London.

\begin{abstract}
This visual essay presents "Database (e)State," an artist and activist-led $\mathrm{Ph}$.D. research project exploring the role of relational databases within urban regeneration processes. Such databases are implicated in Lambeth Council's proposed demolition of Cressingham Gardens Estate in South West London, in the UK. By depicting the problems associated with accessing and comprehending Lambeth's database systems, and then creating a resident-controlled "Shadow Database" of those systems, the essay demonstrates the material, ethical, and political implications of databases in residents' lives and aspirations. Creating the Shadow Database combined activism, art, making, and computer programming within a Critical Technical Practice that draws on histories of technical invention and philosophical theories derived from Gilbert Simondon and Michel Foucault. This practice aims to make the effects of Lambeth's databases more visible and accountable to residents.
\end{abstract}




\section{VISUAL ESSAY}

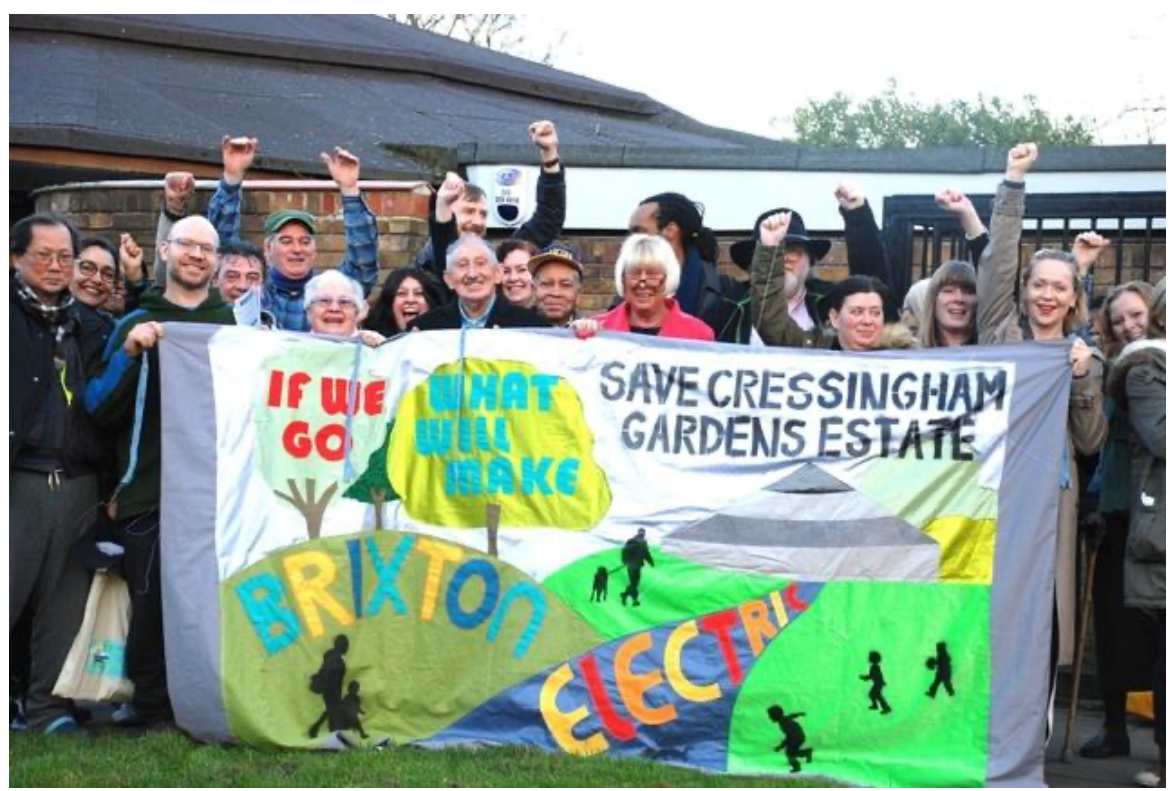

\section{Figure 1. Tom Keene, Cressingham Residents Protesting, 2018, Digital media $\odot$ Tom Keene.}

I have lived as a homeowner on Cressingham Gardens Estate (henceforth Cressingham) in South West London since 2006. Cressingham is under threat of demolition as part of Lambeth Council's (henceforth Lambeth) borough-wide program of urban regeneration. In 2012, a Lambeth housing officer said: "The database told us Cressingham is too expensive to repair." This statement led to my artist and activist-led Ph.D. research project "Database (e)State," which I began in 2015 within the Design Department, Goldsmiths, University of London. The project combines activism, art, making, and computer programming within a Critical Technical Practice that draws on theories of technology and histories of technical invention. ${ }^{1}$ Through this research, and as part of the@SaveCressingham campaign, I revealed and explored the material, ethical, and political implications of housing databases while attempting to prevent the demolition of Cressingham's 306 homes. $^{2}$ 
iLambeth Intranet, PCounter, SCCM, VMWare vSphere, Xen Server, Active Directory, Business Objects XI.i (Northgate Housing Universe), C-Series, Election System (Xpress), Email (don't use on Structure Diagram - use Services CIs), Exchange 2010, Framework, Framework Admin Tool, ImerjaMail, LANDesk, Microsoft .NET Framework, Networker, Northgate Housing, Oneserve, Parking Kiosk, PassMe, SCCM 2012, SharePoint, Telephony - Call Pilot, Telephony - CCM6, Telephony - TM3 (Phone Management), Uniform, Academy, Anite Public Access, CASPAR, Contender, DRS, Framework Business Objects, Framework - Business Objects (InfoView \& Web Intelligence), ICPS Suite, Oracle Enterprise Manager, Oracle RMAN Backup Repository, Public Access -Planning, Query Builder, Visual Files, Zengrab, AIM (Axis Income Management), Cyborg HR, Northgate HAF, Northgate Self Serve Housing Application Form, Oracle Applications Express, Talis, Talis Income Manager, Gandlake, GCSx Outlook Web Access, Genero Desktop Client, Oracle - E-Business, Oracle - HR, Oracle Applications: Accounts Payable, Oracle Applications: Accounts Receivable, Oracle Applications: Cash Management, Oracle Applications: General Ledger, Oracle Applications: PO / iProcurement, PuTTY, Trend Micro Enterprise Protection (Anti Virus), AddressMatch, Address-Point, ADManager Plus, Alto Web Services, ArcGIS (Web GI software), ArcSDE (Server GI software) (supporting web and desktop Gl; spatial data for Symology, Public Access, Artifax Artemis - eBookings, ArtifaxEvent - PDC (Prof Dev Centre), ArtifaxEvent - Registrars, ArtifaxEventOnline (PDC), Asylum Seekers Live, AUTOCAD - Infrastructure Design Suite, AUTOCAD- Building Design Suite, Bacas, Bibliotheca Smart gate Manager, Bibliotheca SmartServe Kiosk, Bibliotheca SmartTunnel Manager, Cashier Kiosks, dataMAP, Directory Equiries - Intranet, Education Management Information Systems, E-forms, Egress, EPIC, Fast Entry, FTPS, Geocortex Hummingbird, iCasework, iCasework Members Enquiry, IMPULSE, InCase Intelligence, Issue Manager, iStorm, JTB Flex Report, Keystone Asset Management System, LAS Console, Leaving Care, Logotech Fixed Assets Register, London Grid for Learning, Marcomm Newsflash, MatchCode, Microsoft

\section{Figure 2. 300+ Lambeth Bureaucracy Machines, 2019, Paper media $\subset$ Tom Keene.}

Rather than a single housing database, I discovered that multiple database systems, software, and hardware components were involved in Lambeth's management of their housing stock. These databases included housing, finance, asset, document, and other interconnected databases that were impossible to comprehend or diagram in their entirety because they were invisible, inaccessible, constantly evolving, and distributed through hardware, software, and network infrastructures. 


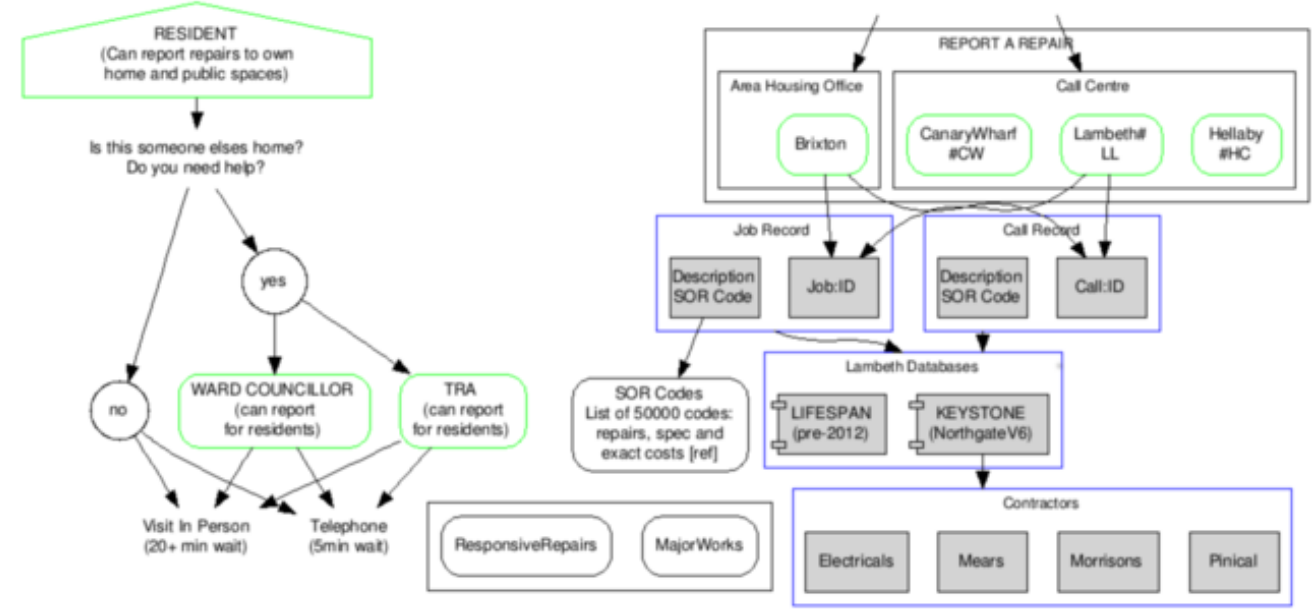

\section{Figure 3. Abandoned Diagram of Lambeth's Database Systems, 2014, Digital media (C) Tom Keene.}

Philosophical literature and art techniques offered ways to address the complexities, ambiguities, and unknowable aspects of Lambeth's databases. The philosopher Gilbert Simondon's 1958 concept of a technical object allowed me to understand a database as an evolving process with multiple associations; it is not a static entity. ${ }^{3}$ The philosopher Michel Foucault's concept of power and knowledge helped articulate Lambeth's databases as a field of strategic possibilities and relations involved in the governance of Cressingham's buildings and residents. ${ }^{4}$ The artist and theorist Graham Harwood's definition of a relational database - as the systematic endeavor of humans and machines to collect and then act on information - then provided a radical understanding of how a database comprises both human and technical components. ${ }^{5}$ These resources led me to draw from my art practice to invent, with intentional black humor, the fictional title Housing Asset and Repairs Management System (HARMS), which defines Lambeth's databases as an unknowable socio-technical collective. ${ }^{6}$ Through this framing, I could focus my attention on what the components of HARMS do rather than what they definitively are. 


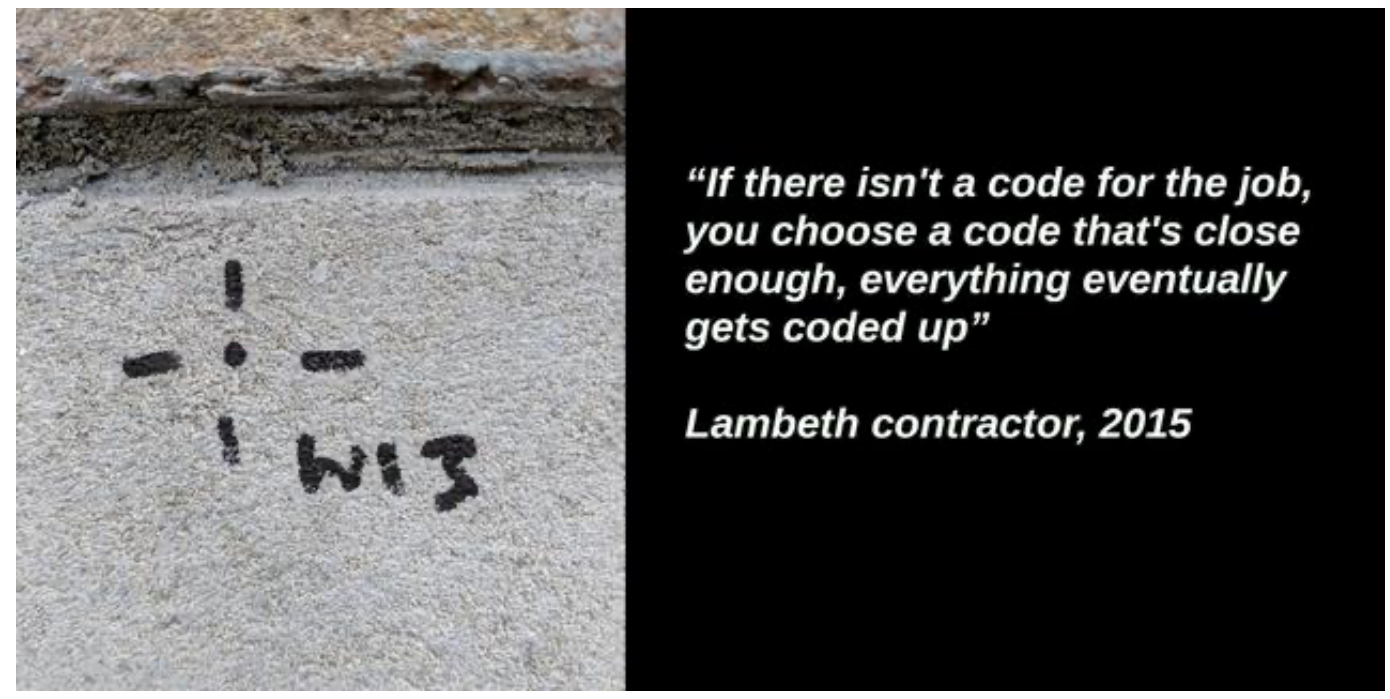

Figure 4. Tom Keene, Everything Gets Coded Up, 2015, Digital media $₫$ Tom Keene.

Working with the@SaveCressingham campaign, I constructed the Shadow Database to reverseengineer hidden data structures while countering Lambeth's insistence that Cressingham was too expensive to repair. Building the Shadow Database informed residents' knowledge of how relational database structures organize Lambeth's housing practices. I deciphered tables and fields of data from snatched conversations with Lambeth staff, cabinet reports, homeowner service charge statements, procurement documents, and over three hundred Freedom of Information Act (FOIA) requests instigated by @ SaveCressingham. This investigation amassed data on over thirty-three thousand tenant, leasehold, and freehold homes across Lambeth, including those on Cressingham, enabling activists to fact-check Lambeth's claims about repairs and avoid longwinded requests for data that often took months and resulted in redacted and error-prone information. 


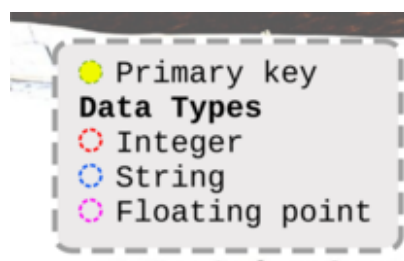

\section{Lambeth}

Estimated and actual day to day annual service charges for the financial year 1 April 2016 to 31 March 2017

\begin{tabular}{|c|c|c|c|}
\hline \multicolumn{2}{|l|}{ ESTIMATED INVOICE NUMBERÁ:- } & \multicolumn{2}{|c|}{ ACTUAL INVOICE NUMBER: 915 is } \\
\hline \multicolumn{2}{|l|}{ ACCOUNT NUMBER: } & \multicolumn{2}{|c|}{ PROPERTY REFERENCE Noś 616} \\
\hline \multicolumn{2}{|c|}{ ESTATE: Çressingham Gardens Ẽstäte } & \multicolumn{2}{|c|}{ BLOCK:îi Hardel Walk } \\
\hline \multicolumn{2}{|c|}{ ESTATE RV: $: 73964$} & \multicolumn{2}{|c|}{ BLOCK RV: } \\
\hline \multicolumn{2}{|l|}{ DWELLING RV::258; } & \multicolumn{2}{|c|}{ FINANCIAL YEAR:í2016/2017; } \\
\hline BLOCK SERVICES & ESTIMATED COST & ACTUAL COST & VARIANCE \\
\hline Boiler Repairs \& Maintenance & 0.00 & 0.00 & 0.00 \\
\hline Cleaning & 0.00 & 0.00 & 0.00 \\
\hline \multicolumn{4}{|l|}{ Communal Electricity } \\
\hline Communal Electrical Maintenance & 0.00 & 0.00 & 0.00 \\
\hline Communal Ventilation Maintenance & 0.00 & 0.00 & 0.00 \\
\hline Communal Water Quality & 0.00 & 0.00 & 0.00 \\
\hline Communal Window Cleaning & 0.00 & 0.00 & 0.00 \\
\hline Concierae & 0.00 & 0.00 & 0.00 \\
\hline
\end{tabular}

\section{Figure 5. Annotated Service Charge Statement, 2017, Paper media (C) Tom Keene.}

As a socio-technical process, HARMS shifts the labor of auditing data and repairs onto residents, impacting their daily lives. A small audit group on Cressingham, comprised of residents, reviewed repairs data and then divided the work of physically inspecting each repair. Those in the group had different demands on their time or limitations on their capacity to undertake this labor. Because of my childcare duties, for instance, I struggled to perform this work, so I built a bike trailer, the "Special Purpose Vehicle," to carry my laptop and amuse my children while I inspected repairs. Through this audit, we discovered over $£ 127,000$ worth of repairs that Lambeth should have claimed on insurance, had charged twice for, were of poor quality, or which contractors had not completed. However, when residents contested these repairs, Lambeth ignored most of our complaints, which prompted some residents into legal action, including a housing tribunal and multiple disrepair claims. In the tribunal, a Lambeth surveyor revealed that their databases coordinate their inspection of only $1 \%$ of repairs, leaving residents to monitor the quality and progress of the majority of contractors' work. HARMS, therefore, is discriminatory because only the most tenacious residents with the time and expertise can successfully contest repairs. 


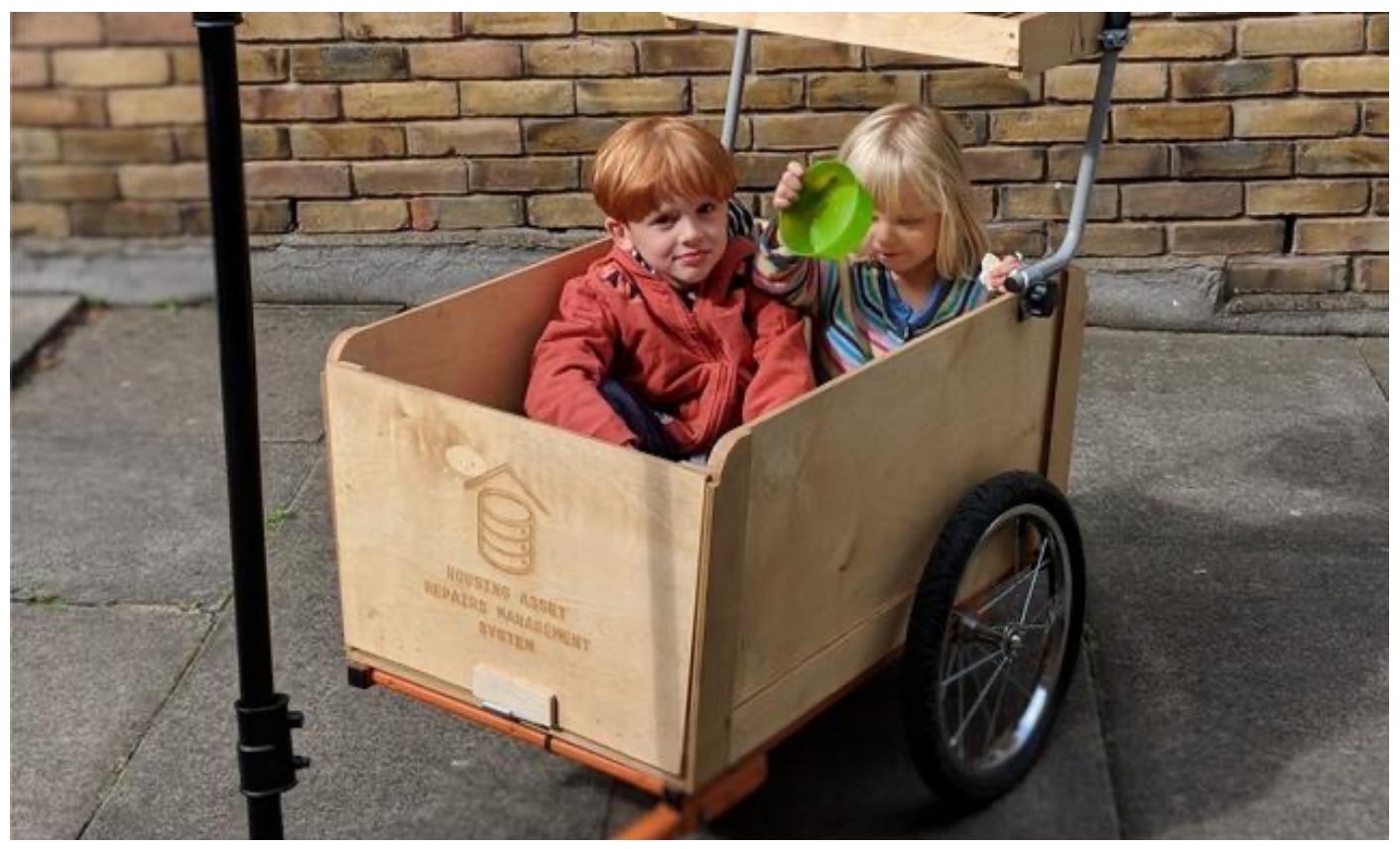

\section{Figure 6. Auditing Repairs with My Kids, 2019, Wooden cycle trailer (C) Tom Keene.}

As a human component of the Shadow Database, I queried data (derived from HARMS) on behalf of residents. I translated residents' questions into a formalized Structured Query Language (SQL) that a database can understand. One query, the "Regeneration Algorithm," presented a list of Lambeth's housing estates in order of the most expensive to repair. I could only assume that a similar algorithm had played a role in Lambeth's consultations and decision to demolish Cressingham. And while these resident-led SQL queries helped challenge the validity of housing data and supported two resident-led judicial reviews of the council decision to demolish Cressingham (one lost; one won), Lambeth continued with plans for demolition. Arguably, HARMS generated such socio-technical complexity that it was impossible to communicate the extent of residents' lived experience of repairs, regeneration, and consultations within judicial processes. Indeed, as one barrister commented, judges are not equipped to understand the scale and complexity of information faced by residents within regeneration schemes, meaning that residents can have little impact on the outcome of council decisions, even when they have access to data and the expertise to question its validity. 


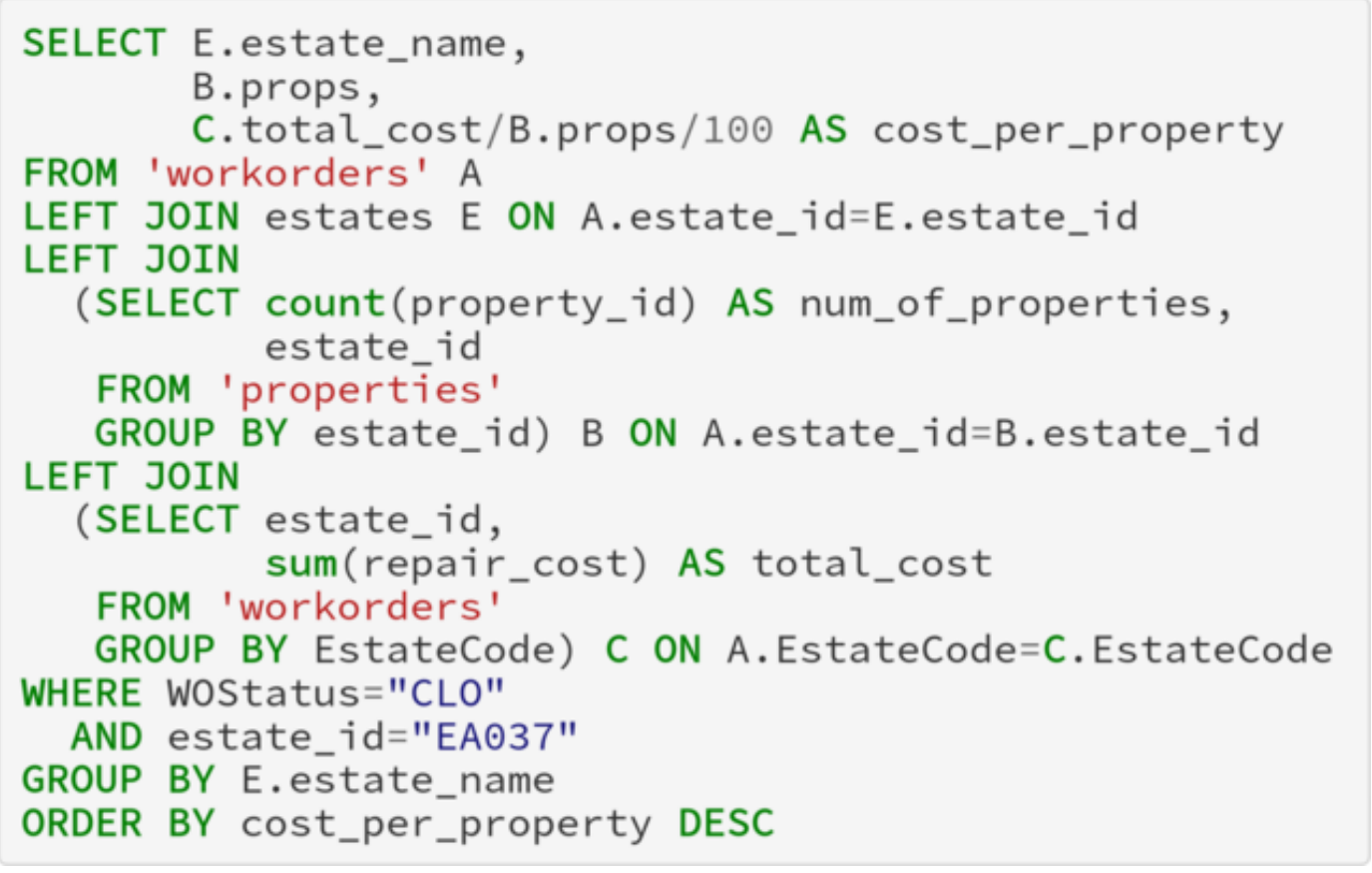

Figure 7. The Regeneration Algorithm, 2015, SQL Code () Tom Keene.

Relational databases operate as a domain of knowledge and action that distributes data, work practices, and accountability through multiple departments and locations in Lambeth. This distribution is a direct product of the first formal definition of the relational database, introduced by E. F. Codd in 1970, which separates the physical storage of data from its logical structure and view. ${ }^{7}$ These technicalities allow HARMS to geographically distribute data, hardware, software, departments, and workers - which generates an ethical detachment from residents' lives.

Residents and Lambeth's workers can find it impossible to comprehend how data come into existence, is acted on, distributed, understood, or incorporated into council calculations and decisions. Accordingly, HARMS configures outcomes that are not always the intent of national and local government and which question the status of government as a terminal point of power, knowledge, and control. 


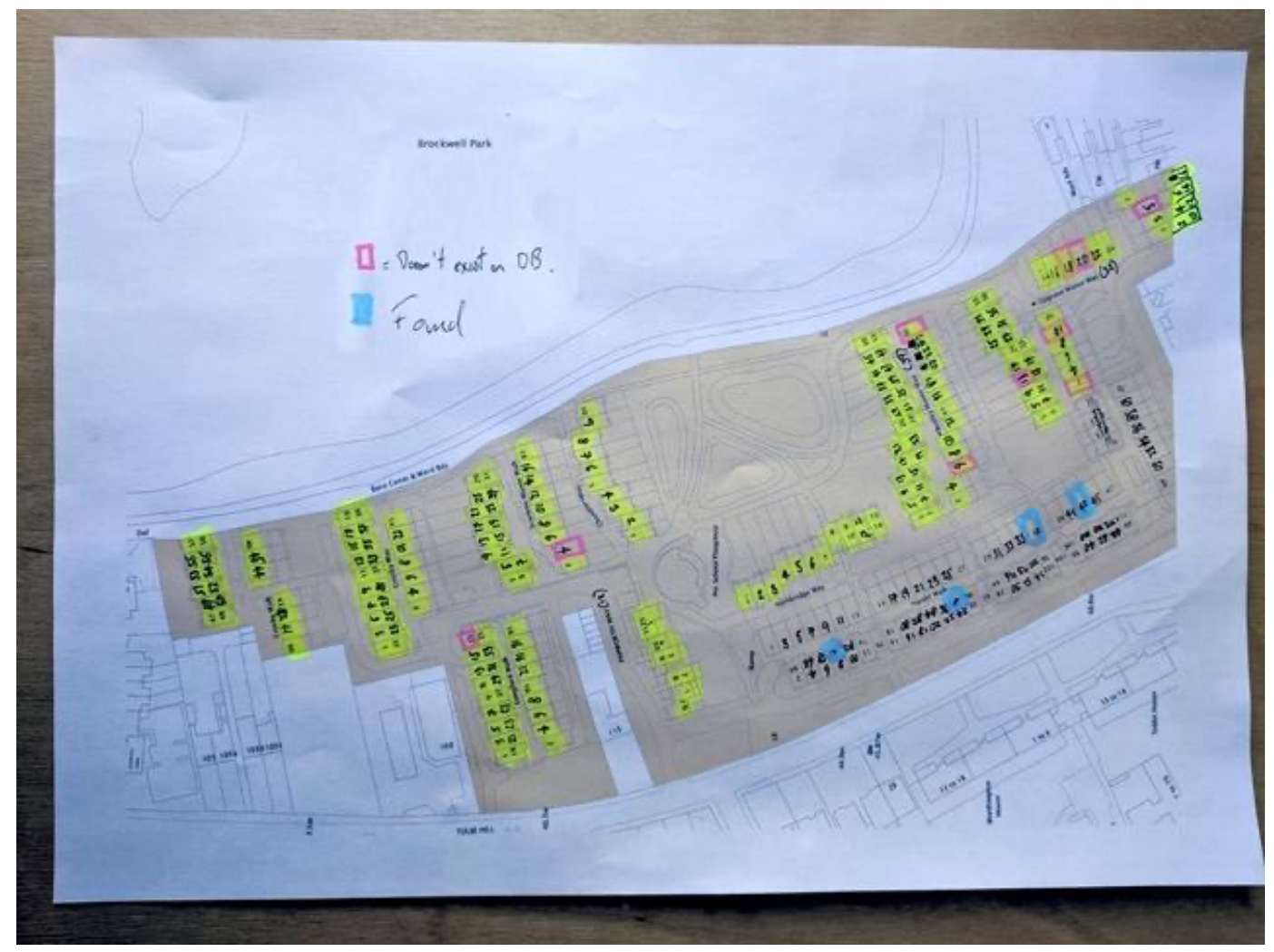

\section{Figure 8. Tom Keene, Homes on Cressingham Were Missing from the Database, 2015, Paper media $@$ Tom Keene.}

HARMS materializes government policies of a Right to Buy, a Decent Homes Standard, and controls over council finances that have emerged with both Labour and Conservative UK governments. Indeed, HARMS recursively generates reports on the condition of housing stock that shape local and national policy, which in turn, produce new data structures and action in Lambeth. These recursive techno-political formations mean that notions of left- or right-wing politics can hold little meaning for Cressingham residents, because HARMS expresses and mediates all vectors of ideological and political aspiration. Lambeth's databases, therefore, can be understood to produce a politics of urban regeneration that is coextensive with government strategy and the affordances of database and network infrastructures. 


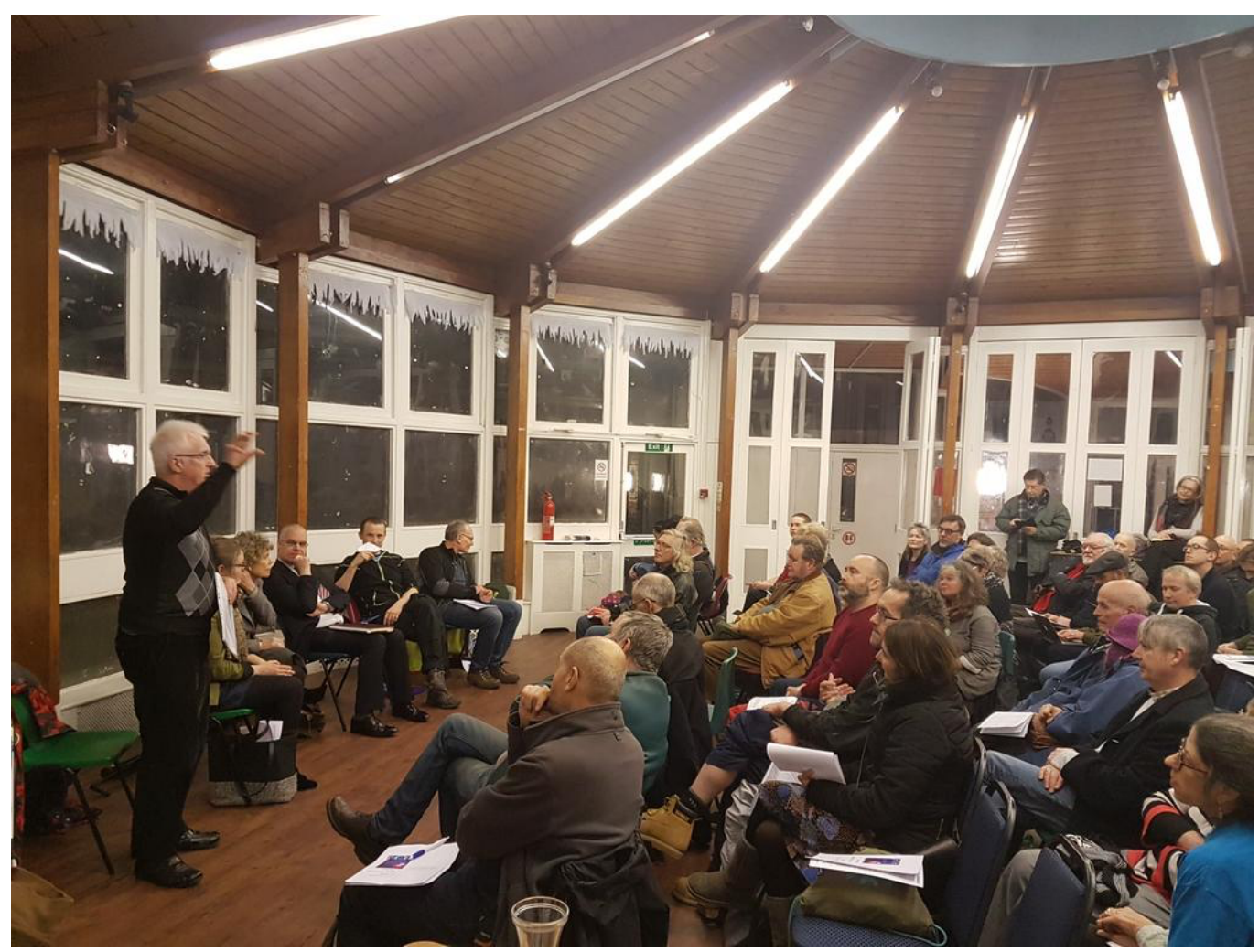

Figure 9. Tom Keene, Audit Meeting on Cressingham Chaired by MP Kate Hoey, 2018, Digital media $(\mathbb{C}$ Tom Keene.

The Shadow Database supported a resident-led application for the legislative Right To Manage (RTM) Cressingham. Enacting the RTM involved a yearlong central government assessment that determined residents were capable of taking over repairs and maintenance services from Lambeth. I deciphered Lambeth's relational database structures (within the RTM process) from FOIA requests, council documents, homeowner service charge statements, and council officers' remarks. I collated a database vocabulary of table and field names within a spreadsheet, which I titled "The Spreadsheet Schema," and which later evolved into the structure of The Shadow Database. This vocabulary worked for residents by applying a formal technical logic to residents' engagement with Lambeth. Council officers who were obliged to decode acronyms and terms while explaining the procedures and material objects they represented. I observed how this vocabulary disciplined council officers' speech and communications by demanding a consistency of language that had eluded residents until that point. Empty fields of housing data (within the Shadow Database) guided residents' requests for information, which slowed down what residents believed were Lambeth's attempts to derail the RTM application. Accordingly, the Shadow Database was instrumental in obtaining a six-month extension to RTM deadlines because it exposed Lambeth's reluctance to provide information. 


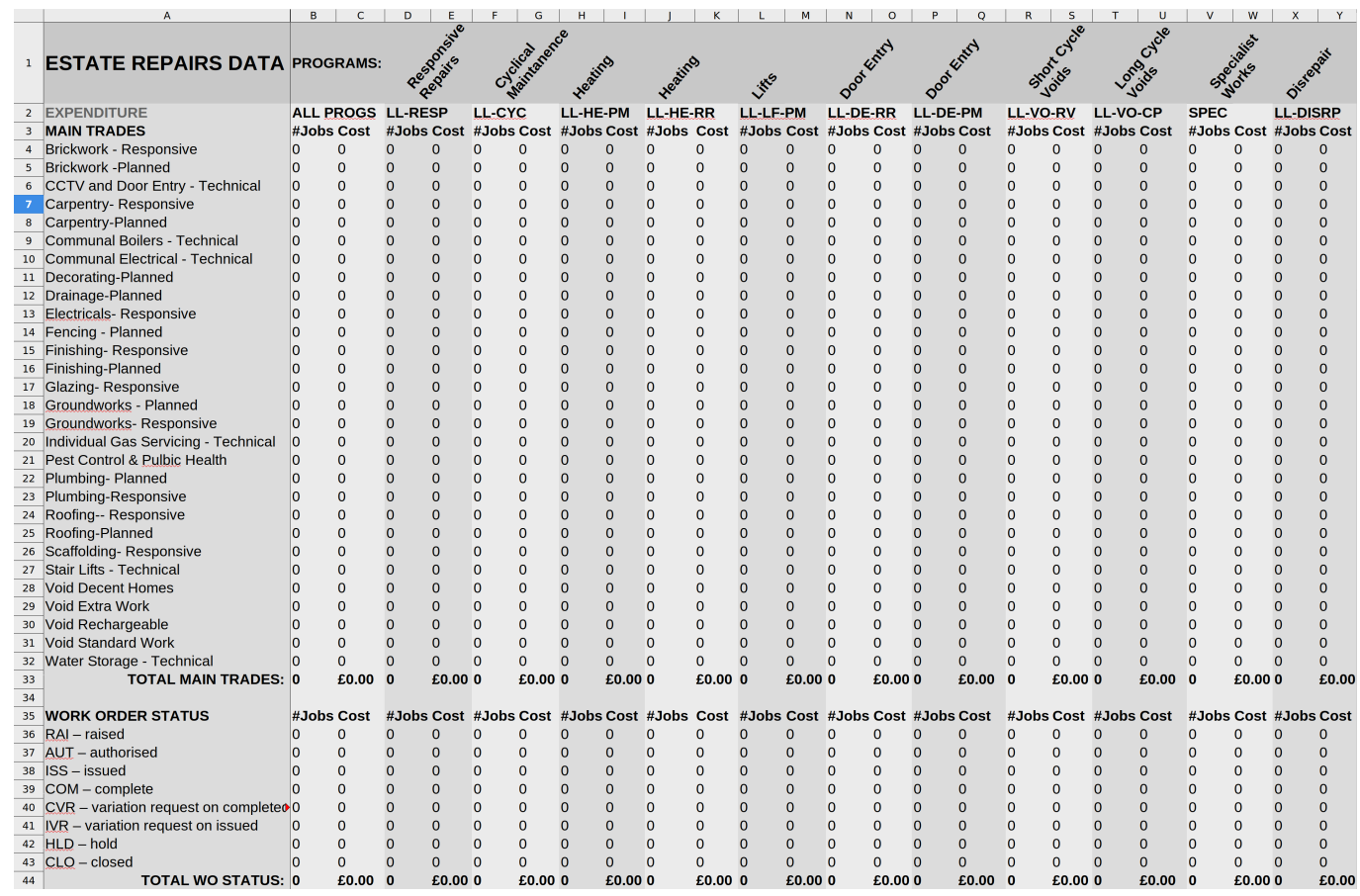

\section{Figure 10. Tom Keene, The Spreadsheet Schema as a Diagram of Power and Knowledge, 2018, Digital media (C) Tom Keene.}

At times, I considered the Shadow Database, Special Purpose Vehicle, Regeneration Algorithm, Spreadsheet Schema, and other artifacts to be art objects. In this way, they became a method of defamiliarizing the reductive logics of databases, government, law, and housing metrics. As art objects they inhabited an ambiguous space between domains of academia, activism, government, law, and my family life - where each impacts the others. Collectively, these art objects paint a portrait of how Lambeth thinks about and acts on Cressingham through their database machinery. More than this, these objects existed as a live diagram of what it means to engage with the dynamics of power and knowledge in the exact moment of encountering, working, or thinking with human-technical collectives. Specifically, the Special Purpose Vehicle pointed to the demands on family life that databases and data put on residents. The Spreadsheet Schema identified the labor, expertise, and legislative milieu required to comprehend Lambeth's database systems, raising issues of democratic accountability and engagement. And the Regeneration Algorithm exposed how database vocabularies configure government-views of people's homes that cannot represent the complexities of residents' lives. These art objects purposefully resist definitive explanation and, instead, provide a glimpse of Lambeth's databases as a process that mediates or organizes human (Lambeth's and residents') aspirations, emotions, and conduct in complex ways. 


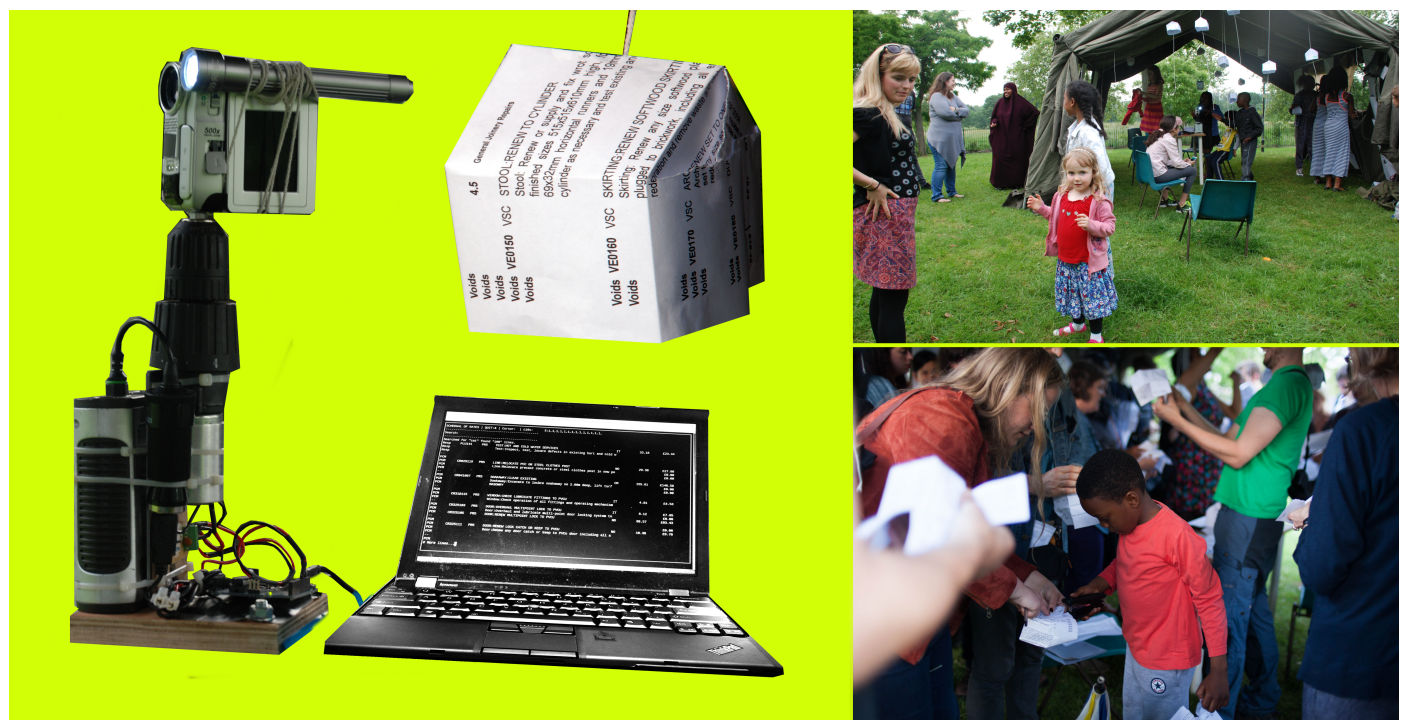

\section{Figure 11. Tom Keene, The Search Drill, 2016, Electronic and paper media (C) Tom Keene.}

The Search Drill was a version of the Shadow Database that was more readily recognizable as an art object than were other artifacts. The Search Drill was a barely-working contraption involving a spinning camera, powered by an electric drill, controlled by a text-based interface with the Shadow Database - surrounded by printouts of codes and categories of repair in the shape of paper houses. The Search Drill event created a humorous and unexpected encounter for Cressingham residents as a counterpoint to the controls of call centers and housing offices that govern how residents submit and obtain information about their homes. The contraption and event generated a feeling of collective ownership and control over a public space on Cressingham, where, for a brief moment, the strategic aspirations of the UK government, Lambeth, and commerce melted away. And by doing so, they focused people's attention on neighborly relations, fun, kids playing, and enjoyment of green space - which are all human experiences that are not accounted for or represented within the technical logic of HARMS or financial calculations of urban regeneration. 


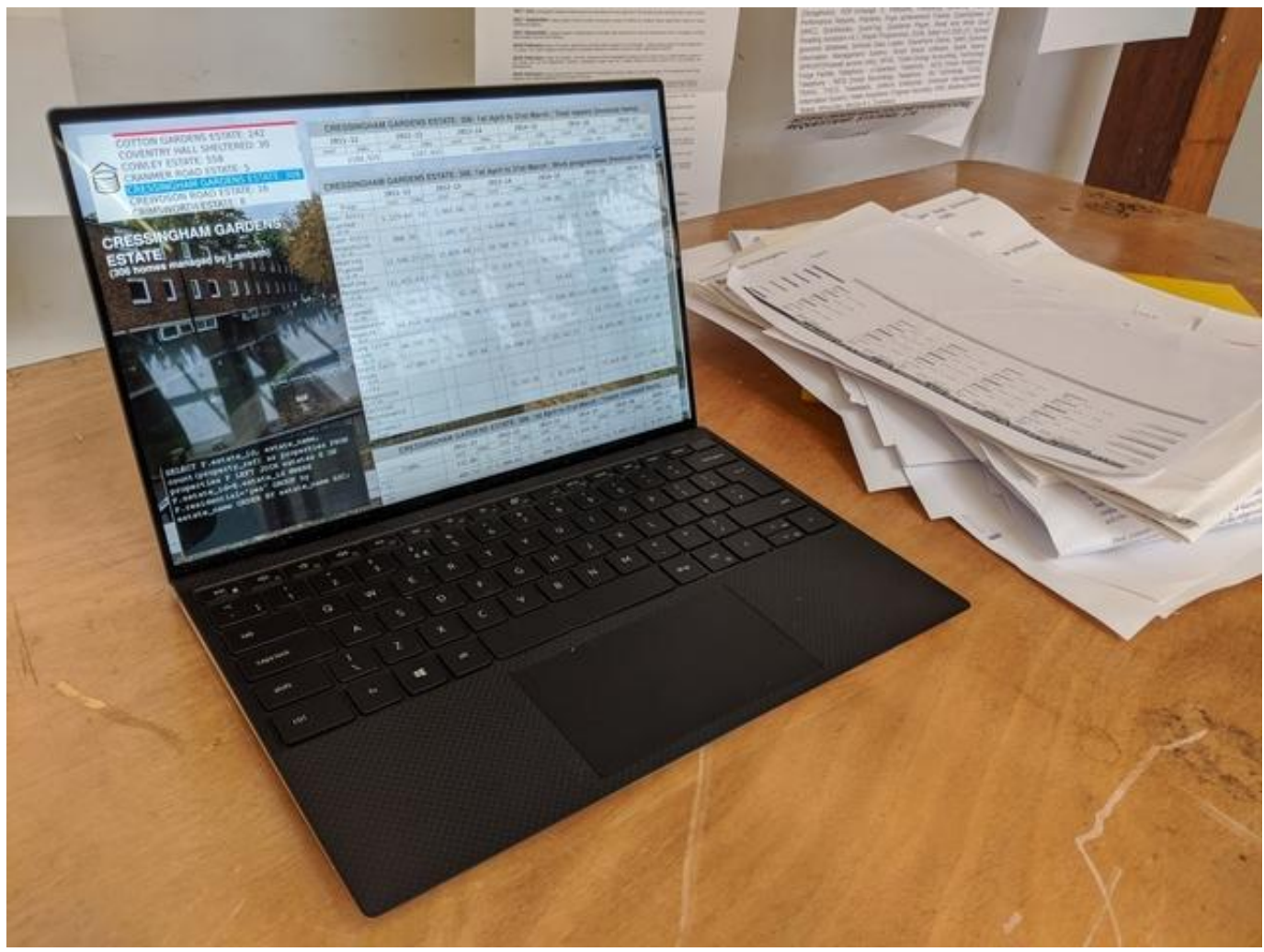

\section{Figure 12. Online, interface to the Shadow database, 2017, Database/Laptop (C) Tom Keene.}

The Shadow Database is more than a software application sitting on a web server or laptop somewhere. It is a more than a technical process involving the labor and expertise of residents and activists, informal networks on Cressingham, and acts of kindness and support in contesting repairs and decisions to demolish homes. Residents can access the Shadow Database, with its human and technical components, via a chat on a walkway, an email, Residents Association meetings, a knock on an activist's window, or a publicly accessible website, bike trailer, or contraption. This informality is a stark contrast to the rigidity and controls enacted through Lambeth's call centers, email systems, and politicians, which exhaust residents into giving up their complaints. And while the Shadow Database has its human and technical gatekeepers that control access to knowledge, it is much closer to home and more accountable to residents than HARMS can ever be. Indeed, the Shadow Database actively supports residents' aspirations for the refurbishment of Cressingham against Lambeth's aspirations for demolition that, residents and activists argue, involves the social cleansing of predominantly poor residents from Lambeth. 


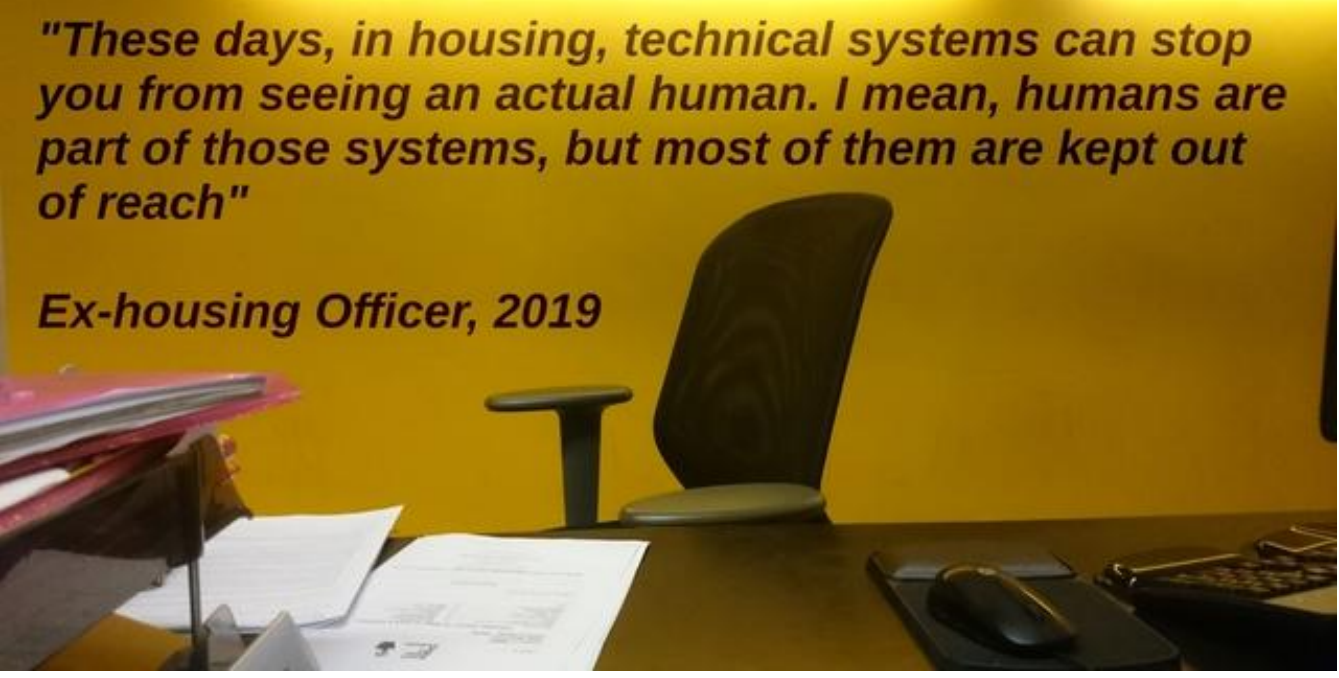

Figure 13. Humans out of Reach, 2019, Digital image (C) Tom Keene.

\section{ENDNOTES}

1. Phil Agre, "Toward a Critical Technical Practice: Lessons Learned in Trying to Reform AI," in Social Science, Technical Systems and Cooperative Work: The Great Divide (Hillsdale: Erlbaum, 1997).

2. Lambeth Borough Council, "Cabinet Report - March 2016, v8," 1. Pdf available at: http://moderngov.lambeth.gov.uk/documents/s80093/Cabinet\%20Report\%20-\%20March\%20201 $6 \% 20 v 8 . p d f$

3. Gilbert Simondon. On the Mode of Existence of Technical Objects, trans. C. Malaspina and J. Rogove (Minneapolis, MN: Univocal Pub, 2016), 26.

4. Michel Foucault, Archaeology of Knowledge (London and New York: Routledge, 2002), 37.

5. Graham Harwood, Database Machinery as Cultural Object, Art as Enquiry (2013), 18.

6. Tom Keene and Kypros Kyprianou, Aristotle's Office (2007). Available at: www.theanthillsocial.co.uk/archive/aristotlesoffice.

6. Edgar Codd, "A Relational Model of Data for Large Shared Data Banks," Communications of the ACM, 13/6 (1970), 377-387.

7. Donald Jardine, "The ANSI/SPARC DBMS Model.” Proceedings of the Second SHARE Working Conference on Data Base Management Systems, Montreal, Canada, April 26-30, 1976, 3. Amsterdam: North-Holland Pub. Co., 1977. 


\section{REFERENCES}

Agre, Phil. "Toward a Critical Technical Practice: Lessons Learned in Trying to Reform AI." In Social Science, Technical Systems and Cooperative Work: The Great Divide, edited by Geoffrey Bowker, Susan Leigh Star, Les Gasser, and William Turner (Hillsdale: Erlbaum, 1997).

Codd, E. F. "A Relational Model of Data for Large Shared Data Banks," Communications of the $A C M, 13 / 6$ (1970), 377-387.

Foucault, Michel. Archaeology of Knowledge (London and New York: Routledge, 2002).

Harwood, Graham. Database Machinery as Cultural Object, Art as Enquiry, Ph.D. thesis, University of Sunderland (2013).

Keene, Tom, and Kypros Kyprianou, "Aristotle's Office” (2007). Available at: www.theanthillsocial.co.uk/archive/aristotlesoffice

Jardine, Donald. "The ANSI/SPARC DBMS Model," Proceedings of the Second SHARE Working Conference on Data Base Management Systems, Montreal, Canada, April 26-30, 1976 (Amsterdam: North-Holland Pub. Co., 1977).

Lambeth Borough Council. "Cabinet Report - March 2016 v8” (2016). Available at: http://moderngov.lambeth.gov.uk/documents/s80093/Cabinet\%20Report\%20-\%20March\%20201 $6 \% 20 \mathrm{v} 8 . \mathrm{pdf}$

Simondon, Gilbert. On the Mode of Existence of Technical Objects, translated by C. Malaspina and J. Rogove (Minneapolis, MN: Univocal Pub, 2016).

\section{AUTHOR BIO}

Tom Keene is an artist, activist, and researcher who investigates the role of marginal and often obscure technological objects. He considers how technical objects construct, transform, and amplify the social relations of everyday life. These objects have included municipal databases, wireless protocol, algorithms, electrical components, automated vacuum cleaners, and biological sensors. 